\title{
Noțiunea de acte urgente în procedura penală
}

dr. Ionuţ NEFLIU *

Rezumat: Articolul tratează actele urgente în procedura penală, care pot fi propuse sau pot fi luate în principiu doar de organele judiciare. Actele urgente sunt actele considerate în mod obiectiv urgente, pentru a evita discreționarismul și opiniile personale ale organelor judiciare.

Și în domeniul actelor urgente, cu anumite limitări de timp, trebuie respectate principiile fundamentale ale procesului penal. Actele urgente nu au un termen îndelungat de efectuare, evită formalismul împovărător și concură la soluționarea justă și într-un termen rezonabil a cauzei penale.

Cuvinte-cheie: acte urgente, neîncepere a urmăririi penale, termen scurt și foarte scurt, procedură în curs, administrare anticipată de probatoriu.

\section{Notion of urgent acts in criminal procedure}

Abstract: The article analyses the urgent acts in criminal procedures, acts that in principle only the judicial authorities can initiate or take. The approach of the notion of "urgent acts" must be objective, in order to avoid discretionary measures or personal opinions of judicial authorities.

Also, in this domain of urgent acts, with regard to restrictions of time, it has to be observed the fundamental principles of criminal trial. The urgent acts don't need a long term to be accomplished, are avoiding the burdensome formalism and are taking part to the justly and timely resolution of criminal cause.

Keywords: urgent acts, before the beginning of investigation, short and very short term, procedure in course, anticipated administration of evidence.

1. În contextul actual al pandemiei cu COVID-19 asociate unui "risc global", cu efecte social-economice imprevizibile este clar că ne îndreptăm spre un drept penal preventiv sau al securităţii preventive ${ }^{1}$, caracterizat de punerea în practică a unor măsuri de prevenție ante

* Asist. univ. asociat al Facultăţii de Drept, Universitatea din București, la disciplinele Teorie generală a dreptului și Doctrine juridice.

Articolul este scris pe baza prezentării materialului Powerpoint din data de 31.03.2020 de către subsemnatul, în cadrul Conferinței online "Urgența în drept" din 30-31 martie 2020, organizată în premieră de Facultatea de Drept a Universității din București.

${ }^{1}$ U. Sieber, Prelegerea susținută la 30 martie 2016 la Universitatea de Vest din Timișoara cu titlul "Schimbarea de paradigmă în societatea dominată de risc global: de la dreptul penal la un drept al securității globale. Analiza noilor limite ale controlului infracționalității" în broșura oferită participanților auditori, p.20 și urm. 
delictum (aşa-numitele pedepse de suspect ${ }^{2}$, potrivit doctrinei italiene, măsuri reglementate în Decretul legislativ nr. 159/ 06.09.2011, id est Codul legilor antimafia și al măsurilor de prevenție $^{3}$ ). Este util, în acest sens, să delimităm stadiul reglementării noțiunii de acte urgente în procedura penală, care și ele prezintă un indubitabil caracter preventiv în special în materia probelor.

Complexul de acte care formează procesul penal constituie o activitate ordonată și progresivă desfășurată atât de organele judiciare, cât și de subiecții procesuali ${ }^{4}$, însă în principiu doar organele judiciare, în virtutea funcției lor procesuale, pot propune sau îndeplini acte urgente.

Reprezintă acte procesuale sau acte procedurale orice acte juridice care realizându-se în procesul penal (sau, mai larg, în procedura penală) produc efecte juridice în procesul penal ${ }^{5}$. Este depăşită sau, în tot cazul, minoritară, viziunea că sunt acte procesuale doar actele care au ca efect imediat nașterea, modificarea sau stingerea unui raport procesual.

Actele urgente nu sunt acte în sensul de negotium iuris (operațiuni juridice), cum ar fi declararea apelului, retragerea plângerii prealabile, renunțarea la apel ${ }^{6}$, ci sunt acte în sensul de acte datorate (onere), necesitate de anumite împrejurări declanșatoare stringente. Fiind acte datorate, îndeplinirea actelor urgente constituie în același timp atât drepturi, cât și obligaţii ale organelor judiciare. Mai mult decât atât, actele urgente sunt actele în mod obiectiv urgente, pentru a fi evitate excesele sau opiniile personale și deci, discreționarismul organelor judiciare.

\footnotetext{
${ }^{2}$ Alături de măsurile de siguranță cu care se confundă parțial, sunt măsuri de prevenție fișa de drum obligatorie, avizul oral al chestorului de poliție, supravegherea specială de siguranță publică (măsuri de prevenție personale), sechestrul și confiscarea (măsuri de prevenție patrimoniale). Deși în principiu Curtea Constituțională italiană s-a pronunțat în mai multe rânduri în favoarea măsurilor de prevenție în dreptul penal, aceste măsuri de prevenție ridică în continuare probleme de constituționalitate și de convenționalitate (Marea Cameră CEDO, în Cauza de Tommaso contra Italiei, 23 feb. 2017, a condamnat statul italian pentru lipsa de previzibilitate a legii care prevede măsura de prevenție de drept penal a supravegherii speciale cu obligația de a rămâne într-un anumit loc).

A se vedea G. Marinucci, E. Dolcini, G. L. Gatta, Manuale di Diritto Penale, Parte Generale, Settima edizione, Giuffrè Editore, Milano, 2018, p. 821.

${ }^{3}$ T. Padovani, Diritto penale, XI edizione, Giuffrè Editore, Milano, 2017, p. 400.

${ }^{4}$ V. Dongoroz \& colectiv, Explicații teoretice ale Codului de procedură penală român, Partea specială, Volumul V, Ediția a II-a, Ed. Academiei Române, Ed. All Beck, București, 2003, p.344.

${ }^{5}$ G. Conso, Istituzioni di diritto processuale penale, Terza edizione aggiornata, Giuffrè Editore, Milano, 1969, p. 186-187.

${ }^{6}$ O. Vannini, Manuale di diritto processuale penale italiano, Seconda edizione aumentata, Dott. A. Giuffrè-Editore, Milano, 1946, p.78.
} 
$\mathrm{Nu}$ toate actele urgente sunt acte procesuale, unele acte sunt efectuate chiar înainte de procesul penal, cum sunt actele aferente instituției actelor premergătoare - art. 224 C.proc.pen. anterior, acte care chiar dacă nu mai sunt reglementate sub C.proc.pen. în vigoare, nu înseamnă că nu există ca atare în plan conceptual.

$\mathrm{Nu}$ trebuie confundate actele procesuale sau procedurale ca acte sau manifestări de voință ale organelor judiciare sau ale părților ${ }^{7}$ ori subiecților procesuali principali cu înscrisurile (instrumentum iuris) care constată existența lor. Forma actului (orală, scrisă) se poate referi la modalităţi de exhibare, de a face actul cunoscut pentru terți (de ex. citarea martorului), dar poate privi și modalităţi de documentare nu numai în scris, dar și pe suport magnetic sau electronic ${ }^{8}$ (cum ar fi declararea orală a apelului, înregistrarea unei convorbiri între coinculpați).

Desigur că în faza urmăririi penale sunt desfăşurate o serie de acte procesuale care trebuie îndeplinite imediat, cu operativitate, dar acest lucru nu semnifică neapărat faptul că toate aceste acte sunt acte urgente. Urgența este dată de caracterul extraordinar și derogatoriu al actelor, de faptul că nu se îndeplinesc uzual, în mod obișnuit și de termenul scurt sau foarte scurt (destul de uşor de identificat prin adverbele "imediat", "de îndată", "fără întârziere") în care trebuie îndeplinite, fără formalități împovărătoare ori inutile.

2. Este vorba nu de urgență, ci de acte procesuale și procedurale operative, atunci când întâlnim, în urmărirea penală, o serie de acte care se subsumează modalităţilor de învestire a organelor de urmărire penală (organe de poliție judiciară, organe speciale de cercetare penală, procurori), de strângere și administrare uzuală a probelor, de promovare a acțiunii penale faţă de suspecții identificați ca făptuitori, în scopul tragerii la răspundere penală și, eventual, la răspundere civilă și a condamnării acestora de către instanța penală.

Astfel, lato sensu am putea considera urgente toate actele îndeplinite în termen scurt în faza de urmărire penală într-o anumită procedură, cum ar fi la percheziție împuternicirea dată organului de cercetare penală de a efectua percheziţia, procesul-verbal de percheziţie, încheierea

\footnotetext{
${ }^{7}$ I. Neagu, Drept procesual penal. Tratat, Ed. Global Lex, București, 2002, p. 456.

${ }^{8}$ G. Spangher, L. Della Ragione, Codice di procedura penale ragionato, con schemi a lettura guidata, VI edizione, Nel Diritto Editore, Molfetta, 2019, p.211.
} 
prin care se dispune arestarea unei persoane fizice, mandatul de $\operatorname{arestare}^{9}$, mandatul de aducere etc.

De asemenea, stricto sensu actele urgente sunt actele considerate ut singuli, spre deosebire de actele dintr-o procedură urgentă (procedura flagrantului sau a luării măsurii preventive) care sunt cum am menționat acte urgente lato sensu. Desigur că legiuitorul poate opta să definească sau să reglementeze noțiunea de acte urgente, dar dacă nu o face, revine doctrinei de specialitate sarcina să delimiteze și să nuanțeze ce acte pot fi calificate drept acte urgente.

Interesul ar fi dublu, pe de o parte dinamizarea procesului penal, iar pe de alta prevenirea rapidă și sigură a unor impedimente, mai ales de ordin probatoriu, care ar putea obstacula desfăşurarea în bune condiții a procesului penal.

Și în această materie, a actelor urgente, cu anumire limitări în special de timp, trebuie respectate principiile fundamentale ale procesului penal: legalitatea, principiul separării funcțiilor judiciare, principiul oficialității, al aflării adevărului și nu în ultimul rând al caracterului echitabil și al termenului rezonabil al procesului penal ${ }^{10}$. Trebuie ținut cont că o societate democratică nu doar consacră în lege (C.proc.pen.) reguli și garanții procesuale, fără ca acestea să fie efective ${ }^{11}$, iar restrângerea lor trebuie să treacă testul caracterului subsidiar, necesar și proporțional cu situația care a creat restrângerea.

Principiul nemijlocirii implică un contact direct al judecătorului cu mijloacele de probă, dar și readministrarea probelor administrate la urmărire penală ${ }^{12}$. Ca și sistematizare, nemijlocirea este tratată în doctrina noastră ca principiu specific fazei de judecată ${ }^{13}$, iar în doctrina portugheză printre principiile privitoare la probe ${ }^{14}$, în acest sens fiind și viziunea legiuitorului portughez (art. 355 C.proc.pen. portughez) ${ }^{15}$.

\footnotetext{
${ }^{9}$ F. Ciopec, Drept procesual penal. Partea generală, Ediția 2, Editura C.H. Beck, București, 2019, p.263.

${ }^{10}$ A. Zarafiu, Procedură penală. Partea generală. Partea specială, Editura C.H. Beck, 2014, p.11 și urm.

${ }^{11}$ L. Violante, Il nuovo codice e il contesto: un impegno difficile ma necessario in Il nuovo codice di procedura penale visto dall' estero, a cura di Mario Chiavario, Giuffrè Editore, Milano, 1991, p.286.

${ }^{12}$ A. Zarafiu, op.cit., p. 355.

${ }^{13}$ Idem, p.353 şi urm.

${ }^{14}$ P. de S. Mendes, Lições de direito processual penal, $5^{\text {a }}$ reimp. da edição de Setembro de 2013, Coimbra, 2018, p.219.

${ }^{15}$ Codigo de processo penal, M.J. Antunes, 21. ${ }^{\text {a }}$ edição, Coimbra Editora, Coimbra, 2015, p. 160.
} 
În Codul nostru de procedură penală nu există o definiție sau o reglementare generică a actelor urgente, însă atât în Codul de procedură penală, cât și în Codul de procedură civilă în vigoare există instituția asigurării anticipate a probei testimoniale (art. 308 C.proc.pen., respectiv art. 359 și urm. C.proc.civ.). Diferența o face, față de procedura penală, faptul că în procedura civilă este permisă asigurarea anticipată a mai multor tipuri de probă (de ex. cu înscrisuri), nu doar a celei cu martori.

Astfel, dacă în procesul civil se ivește necesitatea administrării urgente a unor probe, întrucât până la administrarea lor în fața instanței de judecată acestea pot să dispară sau nu mai pot fi ulterior administrate, atunci partea poate apela la conservarea dovezilor pentru un eventual litigiu sau pentru un litigiu în desfăşurare ${ }^{16}$. Este subliniată în doctrină ${ }^{17}$ obligația solicitantului de asigurare a dovezilor de a demonstra pe lângă condiția de urgență și riscul pieirii probei ori cel puțin dificultatea administrării acesteia. Dacă există acordul pârâtului, urgența nu mai trebuie dovedită (art. 359 alin. 2 C.proc.civ.).

În procedura penală română ${ }^{18}$ este controversată de ex. natura juridică a declarației date de persoana vătămată înainte de începerea urmăririi penale. Întrucât legiuitorul o consideră mijloc de probă, potrivit art. 111 alin. 9 și 10 C. proc.pen. în vigoare, se reține valoarea sa probatorie, deși luarea ei, de îndată, este situată într-un cadru extra-procesual și poate fi calificată ca act premergător începerii urmăririi penale. În doctrină chiar s-au exprimat o opinie în sensul neconstituționalității art. 111 alin. 9 C.proc.pen., în urma modificării acestora prin O.U.G. nr. 18/2016, întrucât apare posibilitatea chiar a condamnării inculpatului pe baza unor mijloace de probă administrate în afara procesului penal, nerespectându-se aparent nici cerințele legalităţii și loialității administrării probelor ${ }^{19}$.

De asemenea, sunt acte urgente unele acte de cercetare penală efectuate în cauză de organele de cercetare necompetente, dar care nu suferă amânare, cum este cazul cercetării la fața locului, potrivit art. 306 alin. 2 C.proc.pen. în vigoare (art. 213 C.proc.pen. anterior ${ }^{20}$ ). Lucrările

\footnotetext{
${ }^{16}$ A. Tabacu, Drept procesual civil. Legislație internă și internațională, doctrină și jurisprudențăa Ed. a II-a, revăzută și adăugită, Universul Juridic, București, 2019, p.302-303.

${ }^{17}$ Idem, p.303.

${ }^{18}$ F. Ciopec, op.cit., p.123.

${ }^{19}$ M.-C. Graur, Acțiunea penală - între oficialitate și oportunitate, Ed. Hamangiu, București, 2019, p. 90 și 92.

${ }^{20}$ A. Crișu, Drept procesual penal, Ed. Hamangiu, București, 2011, p. 399.
} 
efectuate se trimit, de indată, prin procurorul care exercită supravegherea activităţii organului care le-a efectuat, procurorului competent ${ }^{21}$.

Potrivit art. 306 alin. 1 C.proc. pen. în vigoare, implicit sunt acte urgente și luarea măsurilor de către organul de cercetare penală pentru limitarea consecințelor infracțiunii comise, prin întocmirea unui proces-verbal în acest sens.

Termenele foarte scurte și scurte, exprese sau implicite, de ordinul orelor (24 de ore, 48 de ore sau de cel mult 24 de ore etc.) sau zilelor (una, 2, 3 sau 5 zile), în care se îndeplinesc potrivit legii de procedură române unele acte procesuale sau de procedură sunt în opinia noastră un indiciu sigur că acele acte sunt acte urgente.

Astfel, există un termen de 24 de ore pentru soluţionarea cererii de încuviinţare a efectuării percheziţiei domiciliare (art. 158 alin. 5 C.proc.pen. în vigoare).

Alte forme de percheziție (corporală și a unui vehicul) nu trebuie încuviințate în prealabil, putând fi dispuse și de organele judiciare sau de organele cu atribuții în asigurarea ordinii și securității publice, care le și pot efectua ${ }^{22}$. Nu se emite mandat, dar trebuie încheiat un procesverbal, o copie a acestuia fiind lăsată persoanei percheziționate (art. 166 alin. 5 și 6 C. proc. pen. în vigoare). În jurisprudența italiană (o soluție din 5 iul. 1990 a Curții Supreme de Casație ${ }^{23}$ ), s-a statuat că percheziția asupra persoanei supuse procedurii, delegată de procuror poliției judiciare, potrivit art. 247 alin. 3 raportat la art. 370 C.proc.pen. italian nu constituie un act urgent, întrucât este necesară, sub sancțiunea nulității, înștiințarea prealabilă a apărătorului ${ }^{24}$.

3. O referinţă indirectă la urgenţă apărea și în Ordonanţa din 1670 din timpul regelui Louis al XIV-lea (Ordonanța lui Colbert), care prevedea că doar judecătorii și procurorii Regelui puteau primi denunțuri și plângeri, iar în cazul în care existau urme ale infracțiunii, judecătorul

\footnotetext{
${ }^{21}$ Idem, p. 401.

${ }^{22}$ A. Zarafiu, op.cit., p. 355.

${ }^{23}$ L. I. Pisanelli, Indagini preliminare delegate, Rivista di diritto e procedura penale, 1995, Giuffrè Editore, Milano, p. 1168.

${ }^{24}$ Ibidem.
} 
trebuia să se deplaseze imediat la locul faptei și să procedeze la stabilirea faptelor, începând cu adunarea informațiilor de la martori ${ }^{25}$.

Reglementarea actelor urgente se regăsește în Codul de procedură penală italian printre primele articole din Cartea a VII-a, Judecata (este vorba de judecata în primă instanță), cuprinzând actele preliminare judecăţiii (dezbaterii), actele din cursul judecății propriu-zise și actele succesive judecății ${ }^{26}$. Reiese de aici, importanța dezbaterii ca loc privilegiat pentru contradictoriul părților și pentru administrarea probelor, cu respectarea egalității de arme și a terțietății și imparțialității judecătorului.

Potrivit art. 467 C. proc.pen. italian, actele urgente intră în categoria actelor preliminare judecății (dezbaterii) și se dispun de judecătorul italian doar la cererea părții, iar nu doar exclusiv la cererea procurorului (potrivit art. 308 C.proc.pen. român, în procedura audierii anticipate), și privesc doar probele care nu pot fi administrate în cursul judecăţii (prove non rinviabili).

Despre ziua, ora și locul stabilite pentru îndeplinirea actului urgent va fi informat înainte cu cel puțin 24 de ore, Ministerul Public italian, persoana vătămată şi apărătorii interesați. Motivele de urgenţă exclud, potrivit doctrinei italiene ${ }^{27}$, administrarea unei expertize de lungă durată sau a unei mărturii a minorului, ambele proceduri implicând un grad ridicat de complexitate și cu un consum deloc neglijabil de timp, întrucât în cazul minorului este necesară atât prezența părinților săi, cât și a serviciilor sociale de protecție a minorului.

De asemenea, potrivit art. 3 alin. 3 C.proc.pen. italian (dispoziție legală cu caracter general), suspendarea procesului nu împiedică efectuarea actelor urgente.

Potrivit art. 41 alin. 2 C.proc.pen. italian, judecătorul recuzat va putea efectua doar actele urgente în cauză, dacă instanța de recuzare decide astfel, prin ordonanță. Numai actele urgente vor putea fi efectuate de instanța penală italiană și în cazul în care este suspendat procesul datorită incapacității inculpatului (stării sale mentale), ca și atunci când este suspendat procesul penal întrucât a fost sesizată instanța civilă să se pronunțe, ca și chestiune prealabilă, asupra cetăţeniei sau stării civile a inculpatului.

\footnotetext{
${ }^{25}$ A. Battaglia, Processo alla giustizia, Editori Laterza, Bari, 1954, p.75.

${ }^{26}$ G. Spangher, L. Della Ragione, op.cit., p.777.

${ }^{27}$ Idem, p. 780 .
} 
Actele urgente sunt legate însă în special de administrarea anticipată a unor probe și de unele cazuri din cadrul instituţiei incidentului probatoriu (art. 392 C.proc.pen. italian actual), avându-și originea în art. 418 din C.proc.pen. italian de la 1930, care reglementa mărturia de memorie viitoare ("testimonianza a futura memoria"). Este o expresie oarecum improprie, de vreme ce mărturia are loc în mod anticipat pentru un proces în curs, iar nu în mod anticipat pentru un proces viitor, acest lucru nefiind din punct de vedere juridic posibil.

Regula este că, în procesul penal, mărturia se administrează chiar în momentul în care va fi utilizată pentru a servi instrucției sau judecățiii ${ }^{28}$, adică pe scurt pentru a servi judecătorului sau pretorului (magistrat prezent în procedura penală italiană, pe parcursul secolului XX).

Administrarea probei cu martori pentru un moment ulterior al procesului în curs are loc dacă sunt întrunite anumite circumstanțe care fac previzibilă împiedicarea pe viitor a administrării probei și fiind, desigur, necesară și utilă dobândirea probei.

Această inovație exista și în Codul de procedură penală italian din 1913 (Codice Finocchiaro Aprile), ca și în dreptul procesual civil italian (art. 692 C.proc.civ. italian din 1940, în vigoare), fiind calificat un "mijloc de instrucție preventivă". În momentul judecății propriuzise nu se mai impune depunerea unei atari mărturii cu efect viitor, dar dacă mărturia în pretoriu este împiedicată, se procedează la audierea la domiciliu ${ }^{29}$ (sau mai exact de la locul unde se găsește martorul).

Mărturia de memorie viitoare pierde caracterul de mărturie propriu-zisă și derogă de la principiul nemijlocirii, dar se conservă ca probă prin înscrisul respectiv (probă documentară). Ca la orice mărturie, va putea fi admisă proba contrară. Va fi luată în considerare de judecătorul cauzei doar dacă este citită în cursul dezbaterii ${ }^{30}$, observându-se aici efortul legiuitorului italian de a recupera oralitatea specifică acestei probe.

Dacă împrejurările care făceau previzibilă împiedicarea pe viitor a administrării probei nu se confirmă, nimic nu împiedică reaudierea martorului respectiv în faza judecății, fără ca acesta

\footnotetext{
${ }^{28}$ V. Manzini, Trattato di diritto processuale penale italiano, Quinta edizione con le modificazioni del $1955 e$ precedenti, Volume Terzo. Gli atti del proceso penale, Unione Tipografico-editrice Torinese, Torino, 1956, p.287.

${ }^{29}$ Idem, p.289.

${ }^{30}$ Ibidem.
} 
să mai depună jurământul de martor ${ }^{31}$. Nedepunerea jurământului încă o dată de către martorul reaudiat este o altă excepție de la mersul normal al procedurii.

4. Codul de procedură penală portughez $(1987)^{32}$ prevede în art. 320 că președintele de complet îndeplinește, din oficiu sau la cerere, actele urgente și actele a căror realizare cu întârziere ar periclita administrarea sau conservarea probelor sau ar pune în pericol aflarea adevărului, în special luarea declarațiilor în anumite cazuri unor persoane, cum ar fi cele grav bolnave sau aflate în străinătate, dar și cazurile de victime ale infracțiunilor de trafic de persoane sau contra libertății sau autodeterminării sexuale (art. 271 alin. 1 C.proc.pen. portughez).

Potrivit art. 320 alin. 2 raportat la art. 318 C.proc.pen. portughez, sunt acte urgente și luarea de declarații, în mod excepțional și în cazurile prevăzute de lege (anume, persoanele locuiesc în afara jurisdicției instanței, nu există motive să se creadă că prezența lor ar fi esenţială pentru aflarea adevărului, există grave inconveniente pentru aducerea persoanelor respective), persoanei vătămate, părților civile, martorilor, experților sau consultanților tehnici, dacă aceștia nefiind prezenți, se află sub jurisdicția altor instanțe portugheze, urmând a fi folosite mijloace adecvate de comunicare.

De asemenea, potrivit art. 319 acelaşi cod, pentru motive temeinice, din oficiu sau la cerere, pot fi luate declarații și de la domiciliul persoanei vătămate, a părții civile, a expertului sau consultantului tehnic sau de la locul unde acestea se află (spital de ex.). Luarea declarațiilor de la domiciliu se va face, potrivit legii portugheze, fără respectarea publicității ședinței de judecată, așadar cu protecția dreptului la viață privată.

În art. 55, 249 și 250 C.proc.pen. portughez sunt reglementate pentru organele de cercetare penală ce tipuri de acte urgente pot efectua: chiar și din inițiativă proprie, fără a avea ordinul procurorului, se pot sesiza și pot strânge informații despre comiterea infracțiunii, pot descoperi făptuitorii, pot îndeplini actele necesare și urgente pentru a asigura mijloacele de probă, dar au și obligația să împiedice, pe cât posibil, consecințele infracțiunii.

\footnotetext{
31 Idem, p.290.

32 Prevederi similare privind realizarea actelor urgente de către judecător se găsesc și în C.proc.pen. al Republicii Capul Verde (art. 348). În art. 309 alin. 1 al acestui cod se prevede luarea anticipată a mărturiei și în cazul suplimentar al persoanei rămasă fără permis de ședere în Republica Capul Verde.
} 
Despre aceste acte urgente, cu respectarea dreptului la apărare al inculpatului, inclusiv a dreptului acestuia la tăcere, organele de cercetare penală pot chiar depune mărturie în instanţă, întrucât împrejurările respective le-au perceput prin simţurile proprii și nu fac decât să reproducă diligențele depuse și discuțiile avute cu acea ocazie, a decis Curtea de Apel din Coimbra în 16 iunie $2015^{33}$, nefiind vorba aici de o mărturie indirectă și nici de o probă interzisă de dispozițiile legale.

O altă curte de apel portugheză (Curtea de Apel din Evora), printr-o decizie din 24.08. 2017 (proces nr.3 46/15.3GBGDL-A.E1 ${ }^{34}$ ), în acord cu orientarea unanimă în această materie a jurisprudenței curților de apel, a decis că dată fiind, potrivit legii ${ }^{35}$, natura urgentă a proceselor privind infracțiuni de violență domestică, chiar dacă inculpatul nu este arestat, această urgenţă determină curgerea cu celeritate a termenelor procesuale, chiar și pentru zilele de sfârșit de săptămână sau de sărbătoare legală ori vacanță judecătorească (art. 103 alin. 2 C.proc.pen. portughez). În motivarea deciziei, curtea de apel a subliniat că avocaţii inculpatului pot avea dificultăți în exercitarea dreptului la odihnă, dar avocatul rămâne un lucrător liber și pe cont propriu și poate să-și facă vacanța când dorește, dar trebuie să asigure continuitatea serviciului avocațial, chiar dacă trebuie să aibă anumite costuri și renunțări în cazul unor procese urgente. A fost respinsă contestaţia inculpatului, fiind confirmată astfel hotărârea de respingere a recursului acestuia.

5. Actele urgente în procesul penal sunt așadar actele legate în special de materia probelor, sunt acte ut singuli, acte datorate și necesare efectuate de organele judiciare, au caracter obiectiv urgent, au scop preventiv, de regulă sunt luate sau dispuse să preîntâmpine un pericol sau un risc de pierdere sau alterare a probei, nu pot fi efectuate sau repetate ulterior, nu au o durată sau un termen de efectuare îndelungat și concură, bineînţeles, la atingerea scopului procesului penal, acela de aflare a adevărului și de soluționare justă și într-un termen rezonabil a cauzei penale.

\footnotetext{
${ }_{33}^{33}$ Decizie accesată pe 21 mar. 2020, pe site-ul oficial al Curții de apel din Coimbra, Portugalia. http://www.dgsi.pt/jtrc.nsf/8fe0e606d8f56b22802576c0005637dc/82a46d691c727cdf80257e690047bfbb?OpenDocu $\underline{\text { ment }}$

${ }_{34}$ Disponibilă, 3 mai 2020, http://www.dgsi.pt/jtre.nsf/Pesquisa+Livre?OpenForm

${ }^{35}$ Art. 28, cu denumirea marginală "Celeritate procesuală", din Legea portugheză nr. 112/2009 din 16 septembrie privind regimul juridic aplicabil prevenirii violenței domestice, protecției și asistenței victimelor sale.
} 
6. Decretul nr. 195/2020 / 16.03. 2020 al Președintelui României utilizează în art. 42 noțiunea de "cauze de urgență deosebită", care se vor afla pe rolul instanţelor de judecată spre a fi judecate în continuare, pe durata stării de urgență decretate prin actul normativ menţionat (aprobat de Parlament). Lista acestor cauze -stabilește art. 42- se va întocmi de Colegiile de conducere ale Înaltei Curți de Casație și Justiție sau ale Curților de apel potrivit competenței lor sau competenței instanțelor care funcționează în circumscripția lor și va putea fi actualizată. Art. 42 mai prevede că anume Consiliul Superior al Magistraturii va putea emite îndrumări pentru asigurarea unei abordări unitare în stabilirea cauzelor de ugență deosebită.

Deși nu se referă expres la instanțele penale (cu competențe în domeniul dispunerii asupra drepturilor și libertăţilor, în etapa ${ }^{36}$ camerei preliminare sau în faza judecăţii) sau la Parchetele de pe lângă instanțele judecătorești, art. 42 se aplică credem în mod implicit şi acestora. Consecința este că vom avea cauze de urgență deosebită și în penal, fie că sunt definite de lege ca atare, fie că sunt determinate pe cale administrativ-judiciară, după cum permite și legea.

Art. 43 alin. 1 din decret prevede ce tipuri de cauze penale vor fi judecate sau, mai larg, soluționate (întrucât se include și activitatea de urmărire penală) exclusiv pe perioada stării de urgență. Acestea sunt: cauzele în care se iau sau se propun măsuri preventive sau de protecție a victimelor ori martorilor ori se aplică provizoriu măsuri de siguranță cu caracter medical, cauzele în care se iau acte și măsuri urgente pentru obținerea de probe sau prinderea suspecților ori inculpaților, cauzele cu procedura audierii anticipate, cauzele în care se regăsește scopul instituirii în România a stării de urgență (de ex. cauzele având ca obiect infracțiuni de zădărnicire a combaterii bolilor, art. 352 C.pen.). De asemenea, în aplicarea art. 43 alin. 2 din decret, în mod implicit, vor mai fi considerate de urgență deosebită cauzele privind infracțiuni flagrante, cele privind contestațiile la măsurile asigurătorii, cele privind cooperarea judiciară internaţională în materie penală, cauzele privind infracțiuni contra securităţii naţionale, infracțiuni cuprinzând acte de terorism sau de spălare a banilor.

Credem că mai puteau fi cuprinse în decret ca fiind cauze de urgență deosebită și cauzele privind suspecții sau inculpații minori aflaţi în stare de arest sau stare restrictivă de libertate ori pentru care se propune sau se solicită ori se ia în considerare din oficiu schimbarea măsurii preventive luate, ca și cauzele penale privind infracțiuni contra vieții persoanei, ca și infracțiunile săvârșite asupra unui membru de familie (cazurile grave de violență domestică), dacă sunt lezate în mod grav sau sunt puse în pericol în

\footnotetext{
${ }^{36}$ A. Zarafiu, op.cit., p. 355.
} 
mod repetat valorile sociale materializate în drepturi indisponibile ale persoanei sau dacă sunt comise în mod repetat faptele de violență din familie împreună cu un minor ori îndreptate împotriva unui minor.

Acest lucru s-ar fi sprijinit pe ideea preeminenței într-o societate democratică a valorilor sociale strâns legate de persoana umană, ocrotirea persoanei prin mijlocirea legii penale constituindu-se într-unul dintre cele mai importante obiective ale dreptului penal: persoana omului este apărată sub aspectul personalității sale fizice, dar și sub aspectul personalității sale morale (demnitate, libertate) ${ }^{37}$.

Pe de altă parte și minorul indiferent de calitatea sa procesuală, inculpat, suspect, persoană vătămată, martor, trebuie să beneficieze din partea legii de un tratament juridic și psihologic (emoțional) atent și imediat, care să aibă în vedere interesul superior al acestuia și particularitățile sale biopsihice.

În extrasul Hotărârii Colegiului de Conducere a Tribunalului București nr. 8 din 30.03. 2020 se mai arată, printre altele, ca fiind cauze penale care urmează să se judece pe durata stării de urgență ( sunt implicit "cauze de urgență deosebită") și cauzele care privesc amânarea sau întreruperea ori anularea sau revocarea amânării ori întreruperii executării pedepsei, contestațiile având ca obiect liberarea condiționată ori anularea sau revocarea acesteia, contestaţiile la executare și căile de atac extraordinare considerate ca urgente, urgența fiind dată în primul rând, în anumite dosare (de contestație la executare), de existența unei privări de libertate în dosarul respectiv, așa cum prevăd dispozițiile din Hotărârea Colegiului de Conducere a Tribunalului București sus-menționată.

Materialul a fost publicat în revista online a Facultății de Drept, $\underline{\text { AUBD - Forum Juridic nr. }}$ $\underline{2 / 2020 .}$

${ }^{37}$ G. Antoniu, Ocrotirea penală a vieții persoanei, Revista de drept penal nr. 1/2002, R.A. "Monitorul Oficial", p.9. 